UP-265 局所浸潤性前立腺癌 (病期B2\&C) に対する 術前化学内分泌療法による治療勃果の検討

\section{UP-266 前立腺全摘除術における術前内分泌治療の 意義についての検討}

\section{藤田保健衛生大学 医学部 泌尿器科 ${ }^{13}$}

白木 良一”小林 康宏”委原勝孝" 石川清仁" 泉谷 正伸" 星長 清隆"

【目的】局所浸潤性前立腺癌 (病期 B2\&C) 亿対する Estramustine （\&UFT）による術前化学内分泌療法の治療成績を retrospective に検討した。【対象と方法】対象は1996年6月より2000年5月に術 前療法後に前立腺全摘除術を施行し、6力月以上観察期間を有す る局所浸潤性前立腺癌24例。年齢は50～71才(平均 64.3 才)、分化 度はW 6例、M 12例、P6例、であり、治療前PSA值は 5.32 54.0 $\mathrm{ng} / \mathrm{ml}$ (平均 $24.5 \mathrm{ng} / \mathrm{ml}$ )であった。【結果】術前の治療期間は 6 11週(平均 8.5週)で、術前PSA值は $0.05 \sim 1.8 \mathrm{ng} / \mathrm{ml}$ (平均 0.47 $\mathrm{ng} / \mathrm{ml}$ )、PSA減少率は $98.4 \%$ と著明な減少が認められた。摘出 病理での臟器限局例は12例 (50.0\%)で、リンバ節転移は認めなか つた。24例中 16例に臨朱的downstaging老認め、低分化癌6例中 4例が含まれており低分化癌に対しても比較的有効であった。1例 に肝機能障害にて手術を中止したが、投薬中止にて軽快した。術 後観察期間6〜 53 月 月(中央值 28.2 力月)で、死亡例は無く、 progression-free survival は1年 $82.6 \% 、 3$ 年 $54.1 \%$ あった。 【結論】Stage B2 \& C 前立腺癌に対するEstramustine (\& UFT) に上る術前化学内分泌療法は軽度の副作用はあるが、PSAの著明 な減少が短期間に得られた。特に比較的低分化癌に対する術前療 法としてdownstaging等の効果が期待でき、長期予後も比較的良 好であった。

前立腺癌 術前補助療法 前立腺全摘除術

\section{原三信病院 泌尿器科 ${ }^{1}$ 原三信病院 臨床病理部 ${ }^{27}$}

野間 秀哉" 野村 博之"山口秋人" 河野 真司21

【目的】前立腺全摘除術に扔ける術前内分泌治療の意義について 検討した。【対象】1992年1月より2000年10月までに当院におい て前立腺全摘除術を施行し、PSAの評価が可能であった128例 (年 齢51〜76、平均66.6才) を対象とした。【結果】128例中、術前内 分泌治療を施行しなかった群(non-NA)、術前内分泌治療を施行 した群(NA) はそれぞれ61例(年路56 75、平均67.3才) と67例 (年 齢51〜76、平均65.9才)であった。治療前平均PSA值はnon-NAが

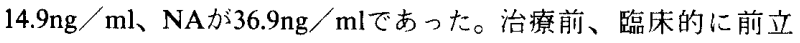
腺に限局していると考えられた症例はnon-NA58例(95\%)、NA37 例(55\%)であった。病理組織学的に前立腺限局癌はnon-NA25例 (41\%)、NA23例 (34\%)であった。NAの前立腺限局癌23例中 7 例(30\%) は非限局癌との治療前診断であった。治療前PSA值が 10 以下、10〜20、20以上にわけると、前立腺限局癌の割合はnon-NA でそれぞれ57、36、25\%、NAでそれぞれ78、55、26\%であった。 【結論】術前内分泌治療の有無で前立腺限局癌の割合に違いはな かったが、術前内分泌治療施行例においてdown stagingが示唆さ れた。組織学的所見、術後補助治療の有無、予後等についても検 討する予定である。

\section{前立腺癌 前立腺全摘除術 術前内分泌治療}

\title{
UP-267 前立腺全摘除術の嵒床的検討
}

\section{UP-268 前立腺全摘除術64例の臨床病理的检討}

\footnotetext{
岐阜市民病院 泌尿器科 ${ }^{1)}$ 土井クリニック ${ }^{2)}$

伊藤 康久 ${ }^{11}$ 土屋 朋大" ${ }^{\prime \prime}$ 土井 達朗 ${ }^{2}$ 山田 伸一郎” 坂 義人 ${ }^{11}$

【日的】前立腺癌に対し前立腺全摘除術を施行した症例を臨床的 に検討した。【対象と方法】1994年8月から2000年8月までに前立 腺全摘術を施行した64例で、年路は54 82歳 (平均69歳)。術前 PSA值（Tandem R) は1.2以下 $661.8 \mathrm{ng} / \mathrm{ml}$ (平均 $65.8 \mathrm{ng} / \mathrm{ml}$ )、 術前の臨床病期はT1a:3例、T1b:4例、T1c:19例、T2a:12例、T2b:9 例、T3:17例であった。術前ホルモン療法は29例に1 18ヶ月、平均 3.5 ケ施行した。【結果】摘出標本の病理診断はpT0:4例、pT2a: 12例、pT2b:10例、pT3a:13例、pT3b:23例、pT4:2例で、 T factor の under stagingはT2aの7例 $(58 \%) 、 \mathrm{~T} 2 \mathrm{~b}$ の 7例 (78\%)、T3の1例 （6\%）にみられた。リンパ節転移はT2aの2例（17\%)、T2bの1例 (11\%)、T3の9例 $(53 \%)$ の計12例にみられた。観察期間は2 73 ヶ月 (平均 35 月) で、PSAが手術後に測定感度 $(0.2 \mathrm{ng} / \mathrm{ml}$ ) 以下になった症例は59例で、そのうち11例（OCD13例中の2例を 含む）にPSAの再上昇がみられた。PSA failure11例中 3 例に膀胱 内再発がみられ、1例に骨転移が出現した。膀胱内再発と骨転移 例の各1例が癌死した。また他因死が3例みられた。

前立腺癌 前立腺全摘除術
}

\section{順天堂大学 䎵尿器科" 順天堂大学 第一病理学 ${ }^{2)}$}

指出一彦“江幡 正悟”小林博仁”島敬之"白井雅人”高島 秀夫" 㙨部英行" 和久本芳彰”坂本 善郎" 藤目 真" 荒川 敦 ${ }^{2}$ 松本 拨治 ${ }^{2}$

【目的】前立腺全摘除術施行例について、リンパ節転移、被膜外 浸潤、精囊浸潤及び外科的断端陽性の頻度について検討する。

【対象】1993年1月から2000年10月までに当科において前立腺全 摘除術を施行した64例を対象とした。TNM分類はUICC 1992年 改訂版に従った。【結果】年齢は48～85歳（平均66.0土6.3）、臨 床病期の内訳は、 T1b 1例、T $1 \mathrm{c}$ 6例、 $\mathrm{T} 2 \mathrm{a}+\mathrm{T} 2 \mathrm{~b}$ 36例、 T2 12 例、T3a 4例、T3b 2例、T3c 3例であった。術前内分泌療法は 38 例 $(59.4 \%)$ に行われ、その期間は1 12力月で平均 3.9 力月であ つた。リンパ節転移は5例（7.8\%）に認められた。また被膜外浸 潤は27例 $(42.2 \%)$ に、精囊浸潤は8例（12.5\%）に認められた。 外科的断端陽性は31例 $(48.4 \%)$ であった。従って64例中32例 (50.0\%) が、病理学的に限局性癌であった。【考察】術前内分 泌療法を行わない荒井の報告（1997）と比べると、リンパ節転移 及び精囊浸潤の頻度は低く、断端陽性の頻度は高かった。また、 全例に術前内分泌療法を行った前田らの報告（1996）と比べると、 断端陽性及び被膜外浸潤の頻度は高く、リンパ節転移及び精囊浸 潤の頻度は低かった。これらの差がついた原因について検討する。 前立腺全摘除術 外科的断端陽性 術前内分泌療法 